\title{
Państwo Islamskie - fenomen nowego dżihadystycznego protopaństwa
}

\begin{abstract}
Streszczenie: W artykule zwrócono uwagę na cztery istotne kwestie: istotę i najważniejsze cechy tzw. dżihadystycznych protopaństw, przegląd wcześniejszych i obecnych dżihadystycznych emiratów, historię Państwa Islamskiego (nazwa ta może być rozumiana dwojako: jako organizacja dżihadystyczna i protopaństwo kontrolujące terytorium), oraz najbliższą przyszłość nowego dżihadystycznego protopaństwa.
\end{abstract}

Słowa kluczowe: Państwo Islamskie, protopaństwo, dżihadyzm, Irak, Syria, terroryzm, walka partyzancka, kalifat

\section{Istota i historia dżihadystycznych protopaństw}

$\mathbf{P}$ owstanie Państwa Islamskiego i ogłoszenie reaktywacji kalifatu wydaje się być z muzułmańskiej perspektywy wydarzeniem ważnym, a być może nawet przełomowym. Z obiektywnego punktu widzenia aktywność ta wpisuje się jednak w działania podejmowane na przestrzeni ostatnich trzech dekad także przez inne grupy dżihadystyczne. Państwo Islamskie wydaje się być, wbrew swej nazwie i wbrew deklaracjom samych dżihadystów oraz opinii niewielkiej części badaczy, tylko ,,protopaństwem”. Czym zatem jest „protopaństwo”? Pierwsza część tego terminu pochodzi z języka greckiego (od słowa ,protos” - pierwszy) i może być tłumaczona w bardzo różny sposób - np. jako „niedoskonały”, „,prymitywny”, „najwcześniej uformowany”, ale też „oryginalny” lub „pierwszy z wielu”. Każde z tych słów w mniej lub bardziej właściwy sposób odnosi się do drugiego członu terminu, a więc do słowa „państwo”, w kontekście analizowanego fenomenu.

Terminologia używana przez Państwo Islamskie (i poprzedzające go byty) ściśle nawiązuje do islamskiej tradycji i nie odbiega od praktyki innych grup dżihadystycznych. Takie terminy jak państwo islamskie (daula islamijja), kalifat (chilafa) czy emirat (imara) pojawiały się w wielu koncepcjach i wdrażanych w życie projektach powołania do życia nowych tworów politycznych wielokrotnie. Brynjar Lia zauważył, iż pierwotnym modelem rządów islamskich był „mały plemienny emirat” (a więc system rządów, w którym władzę sprawuje emir (amir), które to słowo tłumaczyć można jako książę, ale także jako wódz czy dowódca). W odniesieniu do słowa „emirat” Lia przywołał konotacje związane z ,państwem w stanie wojny”, „państwem toczącym dżihad”, ,państwem islamskim" toczącym walkę w imię kalifa i rozszerzającym swe wpływy na obszary nieislamskie” (Lia, 2015, s. 32). Słowo „kalifat” ma odmienne znaczenie i można by rzec - nieco większy ciężar gatunkowy. Historycznie pozytywne konotacje takich terminów jak „emirat” czy „kalifat” tłumaczyć mogą ich współczesną popularność. 
Historia współczesnych dżihadystycznych protopaństw nie jest długa. Pierwsze z nich zaczęły powstawać jeszcze w latach osiemdziesiątych XX wieku. Prawie wszystkie to efemerydy, które istniały od kilku do kilkudziesięciu miesięcy (listę najważniejszych z nich przedstawiono w tabeli 1). Część z nich nie zdobyła nawet kontroli nad terytorium, stąd ich zaliczenie do tej grupy może mieć dyskusyjny charakter.

Tabela 1

Lista współczesnych dżihadystycznych protopaństw (1989-2015)

\begin{tabular}{|c|c|c|c|c|c|}
\hline Nazwa & $\begin{array}{l}\text { Miejsce utworzenia } \\
\text { (państwo, prowincja, } \\
\text { miejscowość) }\end{array}$ & $\begin{array}{l}\text { Okres } \\
\text { istnienia }\end{array}$ & $\begin{array}{c}\text { Kontrola } \\
\text { nad terytorium }\end{array}$ & $\begin{array}{l}\text { Instytucje } \\
\text { cywilne }\end{array}$ & $\begin{array}{c}\text { Zagraniczni } \\
\text { bojownicy }\end{array}$ \\
\hline 1 & 2 & 3 & 4 & 5 & 6 \\
\hline $\begin{array}{l}\text { Dżama’at al Da’wa } \\
\text { - Islamski Emirat } \\
\text { Kunaru }\end{array}$ & $\begin{array}{l}\text { Afganistan / Prowincja } \\
\text { Kunar }\end{array}$ & 1989-1991 & Ograniczona & Brak? & Tak \\
\hline $\begin{array}{l}\text { Al-Dżama’a Al- } \\
\text { Islamijja - Islamska } \\
\text { Republika Imbaby }\end{array}$ & Egipt / Kair / Imbaba & 1989-1992 & $\begin{array}{l}\text { Ograniczona do } \\
\text { małego obszaru } \\
\text { Imbaby }\end{array}$ & Tak & Nie \\
\hline $\begin{array}{l}\text { Grupa Islamskiej } \\
\text { Armii }\end{array}$ & $\begin{array}{l}\text { Algieria / Mitiddża, część } \\
\text { Algieru, Lakhdaria, Medea }\end{array}$ & 1993-1995 & Niepełna & Tak & Niewielu \\
\hline $\begin{array}{l}\text { Islamski Emirat } \\
\text { Afganistanu }\end{array}$ & $\begin{array}{l}\text { Afganistan (prawie cały } \\
\text { w latach 1996-2001) }\end{array}$ & Od 1994 & $\begin{array}{llr}\text { Tak. } & \text { Ok } & 90 \% \\
\text { Afganistanu } & \text { do } \\
2001 & \text { r. } & \text { Spora } \\
\text { część po } & 2001 \text { r. }\end{array}$ & Tak & $\begin{array}{c}\text { Tak. Bardzo } \\
\text { duża liczba } \\
\text { pochodzi } \\
\text { z Pakistanu }\end{array}$ \\
\hline $\begin{array}{l}\text { Dżund al-Islam / } \\
\text { Ansar al-Islam }\end{array}$ & $\begin{array}{l}\text { Irak - część północna / } \\
\text { region Howraman (Bijara, } \\
\text { Tawila i in.) }\end{array}$ & $\begin{array}{l}\text { IX 2001- } \\
\text { III } 2003\end{array}$ & Tak & Tak & Tak. Niewielu \\
\hline $\begin{array}{l}\text { Dżama’at al-Tauhid } \\
\text { wa'l - Dżihad / } \\
\text { Al-Kaida w Iraku / } \\
\text { Islamskie Państwo } \\
\text { Iraku }\end{array}$ & $\begin{array}{l}\text { Irak - część tzw. trójkąta } \\
\text { sunnickiego (Faludża, Ra- } \\
\text { madi) }\end{array}$ & $2004-2008$ & Częściowa & Tak & $\begin{array}{c}\text { Tak. } \\
\text { Duża liczba }\end{array}$ \\
\hline $\begin{array}{l}\text { Al-Kaida, Islamski } \\
\text { Ruch Uzbekistanu, } \\
\text { Terik-i-Taliban }\end{array}$ & $\begin{array}{l}\text { Pakistan / część terytoriów } \\
\text { plemiennych administro- } \\
\text { wanych federalnie, Wazi- } \\
\text { ristan, Północno-Zachod- } \\
\text { nia Prowincja Graniczna }\end{array}$ & Od 2006 & Częściowa & Nie & $\begin{array}{l}\text { Tak. Duża } \\
\text { liczba }\end{array}$ \\
\hline Fatah al-Islam & $\begin{array}{l}\text { Liban / Obóz Nahr el-Ba- } \\
\text { red }\end{array}$ & $\begin{array}{l}\text { Maj-czer- } \\
\text { wiec } 2007\end{array}$ & $\begin{array}{l}\text { Ograniczona kon- } \\
\text { trola nad terenem } \\
\text { obozu }\end{array}$ & $\begin{array}{l}\text { Brak in- } \\
\text { formacji }\end{array}$ & Tak \\
\hline Emirat Kaukaski & Północny Kaukaz & \begin{tabular}{|c|} 
Październik \\
2007 \\
\end{tabular} & Częściowa & Tak & $\begin{array}{l}\text { Tak. Mała } \\
\text { liczba }\end{array}$ \\
\hline $\begin{array}{l}\text { Al-Szabab / Islamski } \\
\text { Emirat Somalii }\end{array}$ & $\begin{array}{l}\text { Południowa i środkowa } \\
\text { Somalia }\end{array}$ & Od 2009 & Tak & Tak & \begin{tabular}{|c||} 
Tak. Duża \\
liczba (m.in. \\
somalijska \\
diaspora)
\end{tabular} \\
\hline Dżunad Ansar Allah & $\begin{array}{l}\text { Palestyna, Rafah, Strefa } \\
\text { Gazy }\end{array}$ & $\begin{array}{l}\text { Sierpień } \\
2009\end{array}$ & $\begin{array}{l}\text { O graniczona. } \\
\text { Tylko meczet Ibn } \\
\text { Tajmijji w Rafah }\end{array}$ & Nie & $\begin{array}{l}\text { Brak infor- } \\
\text { macji }\end{array}$ \\
\hline $\begin{array}{l}\text { Ansar Bajt al-Mak- } \\
\text { dis - Prowincja Synaj } \\
\text { Państwa Islamskiego }\end{array}$ & Egipt - Półwysep Synaj & Od 2011 & $\begin{array}{l}\text { Brak kontroli do } \\
2014 \text { r. Ograni- } \\
\text { czona kontrola po } \\
2014 \text { r. }\end{array}$ & $\begin{array}{l}\mathrm{Nie}-\text { do } \\
2014 \mathrm{r} \text {. } \\
\text { Tak }- \text { po } \\
2014 \mathrm{r} \text {. }\end{array}$ & $\begin{array}{l}\text { Tak. Niewiel- } \\
\text { ka liczba }\end{array}$ \\
\hline
\end{tabular}




\begin{tabular}{|c|c|c|c|c|c|}
\hline 1 & 2 & 3 & 4 & 5 & 6 \\
\hline $\begin{array}{l}\text { Al-Kaida na Półwy- } \\
\text { spie Arabskim - An- } \\
\text { sar al-Szaria }\end{array}$ & $\begin{array}{l}\text { Północna część Jemenu / } \\
\text { Prowincja Abjan (Zindżi- } \\
\text { bar, Dża’ar, Szukra) }\end{array}$ & 2011-2012 & Tak & Tak & Tak. Niewielu \\
\hline $\begin{array}{l}\text { Al-Kaida w Islam- } \\
\text { skim Maghrebie } \\
\text { - Ansar al-Dine / } \\
\text { Islamski Emirat } \\
\text { Azawadu }\end{array}$ & $\begin{array}{l}\text { Północne Mali / Timbuk- } \\
\text { tu, Kidal, Gao }\end{array}$ & $\begin{array}{c}\text { Marzec } \\
2012-2013\end{array}$ & Tak & Tak & $\begin{array}{l}\text { Tak. Niewiel- } \\
\text { ka liczba }\end{array}$ \\
\hline Front al-Nusra & $\begin{array}{l}\text { Syria - część północno- } \\
\text { zachodnia (Idlib) i połu- } \\
\text { dniowo-zachodnia }\end{array}$ & Od 2012 & Tak & Tak & $\begin{array}{l}\text { Tak. Mniejsza } \\
\text { liczba w po- } \\
\text { równaniu } \\
\text { do Państwa } \\
\text { Islamskiego }\end{array}$ \\
\hline $\begin{array}{l}\text { Islamskie Państwo } \\
\text { Iraku i Lewantu / } \\
\text { Państwo Islamskie }\end{array}$ & $\begin{array}{l}\text { Północna część Syrii / Za- } \\
\text { chodnia część Iraku }\end{array}$ & Od 2013 & Tak & Tak & $\begin{array}{l}\text { Tak. Bardzo } \\
\text { duża }\end{array}$ \\
\hline $\begin{array}{l}\text { Madżilis Szura Sza- } \\
\text { bab al-Islam - Ansar } \\
\text { Al-Szaria w Libii - } \\
\text { Prowincje Państwa } \\
\text { Islamskiego }\end{array}$ & $\begin{array}{l}\text { Libia - Derna, Bengazi, } \\
\text { Syrta }\end{array}$ & Od 2014 & Tak, ograniczona & Tak & Tak \\
\hline Boko Haram & $\begin{array}{l}\text { Północna Nigeria / Ada- } \\
\text { mawa, Borno }\end{array}$ & Od 2014 & Tak & Tak & $\begin{array}{l}\text { Tak. Głównie } \\
\text { z Nigru, } \\
\text { Kamerunu } \\
\text { i Czadu }\end{array}$ \\
\hline $\begin{array}{l}\text { Al-Kaida na Półwy- } \\
\text { spie Arabskim }\end{array}$ & $\begin{array}{l}\text { Południowo-wschodni Je- } \\
\text { men }\end{array}$ & Od 2015 & Tak & Tak & Tak \\
\hline
\end{tabular}

Źródło: Opracowanie własne na podstawie Lia, 2015, s. 33-34.

Co łączy wszystkie te projekty? Kluczowych i wspólnych elementów jest niewiele, ale uznać je trzeba za konstytutywne dla wszystkich współczesnych dżihadystycznych koncepcji państwa islamskiego. Pierwszym z nich jest terytorium zamieszkane przez muzułmanów. Drugim elementem jest oparcie porządku ustanowionego na tym terytorium na regułach prawa szariackiego. Trzecim zaś konfliktowy stosunek do własnych sąsiadów i wynikająca stąd niemożność do nawiązania i utrzymania z nimi (ale także z innymi podmiotami państwowymi) jakichkolwiek stosunków. Czwartym wreszcie elementem są dość płynne, by nie rzec umowne granice protopaństw. Granice te rodzą się w ogniu walki i ich przebieg zmienia się tak często, jak zmienia się położenie walczących ze sobą sił na konkretnym obszarze. Stwierdzić zatem można, że protopaństwa funkcjonują poza współczesnym systemem stosunków międzynarodowych, negują jego istnienie, nie uznając porządku formalnoprawnego ukonstytuowanego po II wojnie światowej.

Nieco inaczej do typologii czynników konstytuujących dżihadystyczne protopaństwa podchodzi B. Lia. Jego zdaniem kluczowe są cztery elementy. Po pierwsze: ideologia religijna - protopaństwa oparte są zawsze na projekcie stricte ideologicznym, nawiązującym do prawno-religijnych imperatywów (w tym przypadku do reguł prawa koranicznego) (Lia, 2015, s. 35-36). Po drugie: internacjonalizm - projekty protopaństw mają zawsze internacjonalistyczny charakter. Łączą pod wspólnym sztandarem bojowników 
różnych ras i narodowości wyznających te same poglądy religijne (Lia, 2015, s. 36). Po trzecie: agresywność - dżihadystyczna ideologia uzasadnia, a wręcz sankcjonuje stosowanie i zmusza do użycia siły wobec wszystkich wrogów - wewnętrznych i zewnętrznych (Lia, 2015, s. 36). I wreszcie po czwarte: efektywne zarządzanie - polegające na kompetentnym administrowaniu na zajętym terytorium, w szczególności dostarczaniu wszystkich podstawowych usług publicznych, oraz wprowadzaniu restrykcyjnego systemu wymiaru sprawiedliwości gwarantującego posłuch i bezpieczeństwo zamieszkujących dany obszar społeczności (Lia, 2015, s. 36).

Wydaje się, iż formalna deklaracja utworzenia „emiratu” „państwa islamskiego” czy „kalifatu” ma w takim przypadku znaczenie symboliczne i jest jedynie wezwaniem do szerszego społecznego poparcia projektu, który na szerokie poparcie liczyć raczej nie może z uwagi na wpisaną w jego funkcjonowanie konfliktogenność. Protopaństwa rodzą się w trakcie konfliktu i jak dotąd żadne z nich nie wkroczyło na ścieżkę budowy trwałych struktur państwowych. Wynika to z braku pragmatyzmu ich twórców, co jest zrozumiałe w szczególności z uwagi na ideologiczną (by nie rzec utopijna) czystość projektu, który pragną wcielać w życie. Paradoksem wydaje się być jednak to, że dżihadystyczni stratedzy traktują owe protopaństwa (widać to zwłaszcza w przypadku emiratów) jako ostateczny i przejściowy zarazem efekt swoich działań. Radykalizm ich twórców nie pozwala na ewolucyjne budowanie i wzmacnianie jego struktur oraz poszerzenie bazy społecznej potrzebnej do zrealizowania celu ostatecznego, jakim miałoby być zjednoczenie całej ummy. Warto jednak zauważyć, że Państwo Islamskie od momentu ogłoszenia kalifatu wydaje się być przykładem, który w dużej mierze spełnia wskazane powyżej warunki. Począwszy od czerwca 2014 r., zwłaszcza w 2015 r., sukcesywnie poszerzano jego zasięg terytorialny, tworząc nowe wilajaty i wzmacniając instrumentarium wykorzystywane w ich zarządzaniu. Toczono jednoczenie walkę z wrogiem zewnętrznym i wewnętrznym próbując za wszelką cenę stworzyć przekonanie, iż Państwo Islamskie jest tworem trwałym, budowanym systematycznie w oparciu o ogólnie nakreślony plan.

\section{Geneza i ewolucja islamskiego protopaństwa}

Geneza Państwa Islamskiego sięga przełomu XX i XXI wieku i ściśle wiąże się z ekspansją komórek terrorystycznych Al-Kaidy na terytorium Iraku. Wśród prekursorów tej aktywności wymienić można Abu Musaba al-Zarkawiego, który już w latach dziewięćdziesiątych XX wieku aktywnie zaangażował się na rzecz budowy siatki terrorystycznej w powyższym państwie.

Abu Musab al-Zarkawi (a właściwie: 'Ahmad Fadīl an-Nazāl al-Halāyla) urodził się 30 października 1966 r. w Jordanii, w miejscowości Zarka. Z Al-Kaidą związał się za sprawą o siedem lat starszego rodaka, Abu Muhammeda Essama al-Makdisiego (a właściwie Isama Muhammeda Tahera al-Barkawiego). Obaj poznali się najprawdopodobniej pod koniec lat osiemdziesiątych w pakistańskim Peszawarze (Brisard, 2005, s. 16). To za sprawą al-Makdisiego al-Zarkawi uległ procesowi radykalizacji, co zaowocowało już w latach dziewięćdziesiątych wejściem na ścieżkę dżihadu. Al-Makdisi stał się na początku ostatniej dekady XX wieku mentorem al-Zarkawiego i tych wszystkich dżihadystów, którzy opowiadali się za skrajnie radykalnymi działaniami. 
Swe kryminalne przyzwyczajenia al-Zarkawi starał się przenieść na grunt walki dżihadystycznej. W latach dziewięćdziesiątych był on w związku z tym zaledwie tolerowany przez przywódców Al-Kaidy. Pozwolono mu m.in. kierować w 1999 r. obozem szkoleniowym położonym w pobliżu miejscowości Herat w Afganistanie. Odmówiono jednakże przyjęcia od niego przysięgi wierności (al-'Ubaydi, Lahoud, Milton, Price, 2014, s. 11). Wynikało to najprawdopodobniej z istniejącego konfliktu pomiędzy bin Ladenem a al-Makdisim, rozwijającym się także na płaszczyźnie ideologicznej i niechęcią tego pierwszego do promowania poglądów tego drugiego, za których promocję odpowiedzialny był al-Zarkawi (a związanych np. z projektem budowy nie tylko nowego państwa, ale także nowych struktur społecznych). Abu Musab al-Zarkawi nawiązał w tym samym okresie kontakty z grupą Ansar al-Islam działającą na obszarze irackiego Kurdystanu. Dżihadyści antycypowali najprawdopodobniej już wówczas konsekwencje swych działań ofensywnych, spodziewając się zdecydowanej odpowiedzi Amerykanów w Iraku. Nie bez znaczenia wedle niektórych badaczy były także konotacje historyczne związane z okresem wypraw krzyżowych i sukcesów Nur ad-Dina i Saladyna (kontrolujących znaczne połacie Syrii i Iraku). Al-Zarkawi przeniósł się do Iraku po upadku Islamskiego Emiratu Afganistanu w drugiej połowie $2001 \mathrm{r}$.

Najprawdopodobniej już w 1999 r. (Lister, 2014, s. 6) powstała grupa nosząca nazwę „Dżamat al-Tauhid wa-al-Dżihad” (Organizacja Monoteizmu i Świętej Wojny, OMŚW) (Zelin, 2014, s. 1). Była ona odpowiedzialna za szereg zamachów terrorystycznych w kolejnych latach (na szyickie meczety, irackie instytucje rządowe i cywilów), w tym za zamach na siedzibę ONZ w Bagdadzie i zabicie w dniu 19 sierpnia 2003 r. Sergio Vierio de Mello - Specjalnego Przedstawiciela Sekretarza ONZ w Iraku. Z taktycznego punktu widzenia powyższa organizacja łączyła walkę partyzancką z terroryzmem (o czym świadczą choćby: udział w pierwszej bitwie o Faludżę czy atak na instalacje naftowe w Basrze w kwietniu 2004 r.) (Web, 2004). Sukcesy Dżamat al-Tauhid waal-Dżihad zaowocowały także zacieśnieniem relacji al-Zarkawiego z al-Kaidą na jego własnych warunkach. Przejściowe zaakceptowanie przez bin Ladena posłuszeństwa alZarkawiego miało taktyczne podłoże. Al-Kaida pragnęła bowiem, w związku z amerykańską inwazją na Irak, umocnić w tym państwie swe wpływy, a taktyczny sojusz z komórkami al-Zarkawiego wydawał się wówczas najbardziej racjonalnym wyborem (Fishman, 2008, s. 47). Aby podkreślić nowy etap w rozwoju wzajemnych relacji, sieć komórek kierowanych przez al-Zarkawiego zyskała w 2004 r. nową nazwę w postaci: Al-Kaida w Mezopotamii (Tanzim al-Ka'ida fi Bilad al-Rafidajn). Nazwa ta często zamiennie używana jest z inną: Al-Kaida w Iraku (Lister, 2014, s. 8).

Al-Kaida w Iraku od samego początku swego istnienia działała w sposób wybitnie autonomiczny (zarówno wtedy, gdy zadeklarowano wojnę z szyitami w Iraku, jak i wtedy, gdy postanowiono rozszerzyć aktywność terrorystyczną na sąsiednie państwa), co spotkało się z krytyką władz Al-Kaidy, w tym Ajmana al-Zawahiriego. Krytyka dotyczyła przyjętej taktyki, która zdaniem przywódców al-Kaidy (w tym także Atijjatullaha al-Libiego) mogła negatywnie wpłynąć na realizację celów dżihadystów w Iraku (Fishman, 2008, s. 48). Przejawem tejże taktyki był choćby atak zamachowców-samobójców na trzy hotele w Ammanie (Jordania) w dniu 9 listopada 2005 r., w którym zginęło 60 osób, a 115 zostało rannych (Jordan, 2005). Choć powyższa krytyka nie miała $\mathrm{w}$ istocie publicznego charakteru, to wpłynęła jednak na zmiany, do których doszło na 
początku 2006 r. Jednym z wielu powodów, który do tych zmian doprowadził było także pojawienie się wielu nowych grup dżihadystycznych po upadku reżimu Saddama Husajna w 2003 r. Wiele z nich zaczęło działać w autonomiczny sposób, odmawiając współpracy z grupą al-Zarkawiego. Część z nich zjednoczyła się w ramach powstałej w dniu 15 stycznia 2006 r. Rady Konsultacyjnej Dżihadystów w Iraku (Madżlis Szura alMudżahidin fi al-Irak). Na jej czele stanął Abdallah bin Raszid al-Baghdadi (Abu Umar al-Baghdadi). Al-Kaida w Iraku obok kilku innych grup weszła w skład tego nowego tworu organizacyjnego.

Żołnierzom amerykańskim udało się zabić al-Zarkawiego w czerwcu 2006 r., co, jak się wydawało, zakończyć miało aktywność dominującej grupy dżihadystów w Iraku (Gerges, 2014, s. 339). Tak się jednak nie stało. Po śmierci al-Zarkawiego w czerwcu 2006 r. schedę po nim przejął Abu Hamza al-Muhadżir, który niemal natychmiast podporządkował się „Ojcom Założycielom” Al-Kaidy. Jednakże już kilka miesięcy później przywództwo nad komórkami Al-Kaidy w Iraku przejął Abu Umar al-Baghdadi. Powstała w dniu 15 października 2006 r. grupa przyjęła nazwę: Islamskie Państwo Iraku (IPI - Daula al-Irak al-Islamijja) (Lahoud, al-'Ubaydi, 2014, s. 2). Nazwa ta była w użyciu aż do kwietnia $2014 \mathrm{r}$. W istocie w jej skład weszły ugrupowania wcześniej zjednoczone w ramach Rady Konsultacyjnej Dżihadystów w Iraku, w tym Al-Kaida w Iraku. Te, które odmówiły podporządkowania się IPI zostały w połowie 2007 r. rozbite, a ich kierownictwo uśmiercone. Dotyczyło to m.in. organizacji al-Dżaisz al-Islami, Ansar al-Sunna i Dżaisz al-Mudżahidin. Pozostali przy życiu dżihadyści nienależący do ISI wezwali bin Ladena do całkowitego zerwania więzów z Islamskim Państwem Iraku.

Walka zbrojna była jednym $\mathrm{z}$ wielu, ale nie jedynym celem nowopowstałej grupy (Fishman, 2008, s. 49). Równie ważne miały być działania na płaszczyźnie politycznej, w tym powołanie do życia instytucji, które miały przejąc obowiązek zarządzania różnymi sektorami nowego państwa. Al-Baghdadi w kwietniu 2007 r. ogłosił powołanie dziesięciu ministerstw, które nigdy efektywnie nie zaczęły działać (w tym ministerstwo zdrowia, ministerstwo ropy naftowej i ministerstwo rolnictwa) (al-'Ubaydi, Lahoud, Milton, Price, 2014, s. 14). Decyzje te, podjęte zapewne bez porozumienia z przywódcami Al-Kaidy, nie spotkały się z ich zrozumieniem. Ajman al-Zawahiri ocenił te posunięcia jako błąd polityczny, a propagatorów tego typu działań nazwał ekstremistami, działającymi impulsywnie i niemądrze (al-'Ubaydi, Lahoud, Milton, Price, 2014, s. 15). Po śmierci Abu Umara al-Baghdadiego i Abu Hamzy al-Muhadżira w kwietniu 2010 r., kierownictwo w IPI przejął Abu Bakr al-Baghdadi. Mimo braku formalnej deklaracji ze strony bin Ladena relacje pomiędzy Islamskim Państwem Iraku a Al-Kaidą zamarły już wówczas całkowicie, co było skutkiem procesu rozpoczętego jeszcze za życia al-Zarkawiego. Nikt z przywódców Al-Kaidy nie uznawał jednostronnej deklaracji IPI o utworzeniu Państwa Islamskiego, uznając tego typu działania za szkodzące sprawie dżihadystycznej i wprowadzające podziały pomiędzy różne grupy dżihadystyczne.

Sytuację pogorszyła deklaracja al-Baghdadiego z kwietnia 2013 r., która wiązała się z proklamowaniem powstania Islamskiego Państwa Iraku i Lewantu (IPIL) (Daula alIslamijja fil- 'Irak ash-Sham, znanego także pod nazwą Islamskiego Państwa Iraku i ashSham lub Islamskiego Państwa Iraku i Syrii). Nowa grupa powstała z połączenia Islamskiego Państwa Iraku z syryjską grupą Dżabhat al-Nusra (Dżabhat al-Nussrah li-Ahli ash-Sham, czyli Front al-Nusra lub też Front Poparcia dla Ludu Syryjskiego - FN). Ta 
ostatnia organizacja powstała w Syrii w styczniu 2012 r., zaś jej członkowie aktywniej zaangażowali się w konflikt w Iraku, niż w Syrii. Decyzję o połączeniu z ISI odrzucił wpierw szef FN - Abu Muhammad al-Dżulani, potwierdzając podporządkowanie przywódcom al-Kaidy. Ponadto w czerwcu 2013 r. Ajman al-Zawahiri anulował jednostronną decyzję al-Baghdadiego (al-Tamimi, 2014, s. 5-6), wyznaczając Abu Chalida al-Suriego (członka syryjskiej grupy Harakat Ahrar ash-Sham) na arbitra w powyższym konflikcie (al-'Ubaydi, Lahoud, Milton, Price, 2014, s. 16-17). Dla al-Baghdadiego próba przejęcia kontroli nad FN była związana z chęcią zawłaszczenia wpływów nad całym ruchem dżihadystycznym w regionie i przejawem niechęci do idei nacjonalistycznych, którym Dżabhat al-Nusra przeciwna raczej nie była. Walka o wpływy wkroczyła w nowy etap w grudniu 2013 r., kiedy to członkowie IPIL porwali i zamordowali Abu Sada al-Hadramiego, przywódcę FN w syryjskiej prowincji al-Rakka.

Na początku stycznia 2014 r. oddziały Islamskiego Państwa Iraku i Lewantu przybyły do ar-Ramadi z deklarowanym celem obrony lokalnej sunnickiej społeczności. Zostali oni wkrótce wyparci z tego obszaru. Nie zatrzymało to jednak ofensywy ISIL i zajęcia nowych obszarów w Iraku i Syrii. W tym drugim państwie bojownicy ISIL oskarżani byli o liczne przestępstwa i ,niedopuszczalne” praktyki w imię dżihadu (al-'Ubaydi, Lahoud, Milton, Price, 2014, s. 24). Abu Chalid al-Suri, piętnujący te zachowania, został w lutym 2014 r. skrycie zgładzony. Choć IPIL była najważniejszą grupą podejrzewaną o to morderstwo, to nigdy do niego członkowie tej grupy się nie przyznali. Islamskie Państwo Iraku i Lewantu nie zastosowało się ponadto do wezwania al-Zawahiriego i nie podporządkowało się przywódcom Al-Kaidy. Członkowie Frontu al-Nusra natomiast nie tylko nie podporządkowali się decyzji al-Baghdadiego, ale podjęli działania mające na celu wyparcie IPIL z zachodniej części Syrii (m.in. Aleppo czy Hamy) zmuszając do ograniczenia jego wpływów do okolic miasta al-Rakka nad Eufratem.

Zmiana nazwy grupy al-Baghdadiego na Państwo Islamskie (PI), co stało się pod koniec czerwca 2014 r., jest próbą rozszerzenia aktywności dżihadystów na obszar poza Irakiem i Syrią. Oczekiwany od tak dawna powrót do idei kalifatu zaowocował w końcu ostateczną decyzją. Potwierdzenie powyższego wydarzenia miało miejsce w dniu 4 lipca 2014 r. w specjalnym wystapieniu al-Baghdadiego w meczecie w al-Rakkce. Oznajmił w nim, że głównym celem restytucji kalifatu jest zjednoczenie całej ummy.

\section{Instytucja kalifatu i funkcje kalifa}

Restytucja kalifatu wpisała się w historię podobnych prób z ostatniego ćwierćwiecza. Deklaracja Państwa Islamskiego o utworzeniu kalifatu ma przede wszystkim znaczenie symboliczne. Po upadku kalifatu otomańskiego utworzenie nowego kalifatu było oczekiwane i pożądane. Projekt państwa jednoczącego całą społeczność islamską jest bowiem silnie zakorzeniony w islamskiej historii. Czym zatem jest kalifat i jakie są funkcje kalifa?

Słowo kalifat (chiläfa) oznacza w języku arabskim islamski ustrój polityczny, w którym główną rolę odgrywa kalif (chalīfa). Tytuł kalifa niesie ze sobą znaczące historyczne konotacje, a w najprostszym tłumaczeniu oznacza następcę (czy zastępcę) Proroka Mahometa. Wielu badaczy uważa, że idea kalifatu jest tematem przewodnim islamskiej 
myśli politycznej oraz podstawowym elementem konstytuującym teorię współczesnego państwa islamskiego (Adam, 2001, s. 20). Mylnie utożsamia się kalifat z wieloma innymi systemami rządów lub sposobami organizacji państwa, uznając go za podobny do monarchii, imperium, republiki czy federacji, nie zauważając jego oczywistej wyjątkowości. W klasycznym systemie monarchicznym nie pojawiają się takie sposoby wyłaniania monarchy jak złożenie przysięgi wierności ( $b a$ ’ja) przez ummę. Monarcha zazwyczaj dziedziczy władzę, którą posiada po innych członkach rodziny. Postawiony jest zazwyczaj ponad prawem lub sam stanowi prawo. Posiada specjalne przywileje, a jego władza jest absolutna. Kalif nie posiada pozycji równej królowi w systemie monarchicznym, nie jest symbolem państwa, a jedynie przedstawicielem ummy. Jest też ograniczony regułami prawa szariackiego i zobowiązany dbać o interesy muzułmańskiej społeczności (Khilafah, 2005, s. 10-11). Ustrój polityczny kalifatu nie ma charakteru republikańskiego. Republiki pojawiły się jako odpowiedź na tyranię monarchów. W republikańskim systemie rządów władza należy nie do monarchy, ale do ludu, który sprawuje władzę za pomocą wyłonionych przez siebie przedstawicieli. Władzę republikańską wyłania się w procesie demokratycznym, który legitymizuje prerogatywę stanowienia przez nią prawa. Monteskiuszowski trójpodział władzy, konstytuujący porządek demokratyczny we współczesnych liberalnych republikach jest jego istotną emanacją. W przypadku kalifatu władza stanowienia porządku panującego w tym państwie należy tylko do Allaha. Scedowanie tego prawa na lud jest zaprzeczeniem tego porządku. Islamski system rządów nie ma zatem demokratycznego charakteru w ścisłym znaczeniu tego słowa (Khilafah, 2005, s. 12-13). Kalifat nie powinien być też utożsamiany w sensie dosłownym z imperium (choć historycznie wiele kalifatów, zwłaszcza z perspektywy świata zachodniego, do takiego miana pretendowało). System zarządzania i podporządkowywania prowincji metropolii jest obcy idei kalifatu. System imperialny ma charakter scentralizowany. Oparty jest na rozdawnictwie przywilejów i skupiony na utrzymaniu zależności od centrum. W przypadku kalifatu wszystkie jednostki organizacyjne mają ten sam status, a jego obywatele bez względu na rasę czy pochodzenie cieszą się tymi samymi prawami (Khilafah, 2005, s. 11). Kalifat nie jest także federacją, rozumianą jako związek mniejszych państw związkowych posiadających wspólny rząd. Zdaniem Hadrata Zafrulla Khana kalifat jest ostateczną emanacją państwa islamskiego, w którym ziszczają się najważniejsze islamskie ideały, zarówno duchowe, jak i społeczne: w szczególności, oprócz swobód religijnych, możliwość życia w pokoju i współpraca mająca na celu budowanie dobrobytu społecznego. W związku z uznaniem nadrzędności porządku naturalnego nad stanowionym idea kalifatu stoi ponad ideą suwerenności narodowej i związanymi z nią podziałami etniczno-kulturowymi (Ahmad, 2016). Mając na uwadze powyższe rozważania skonstatować można, że kalifat można uważać za formę państwa unitarnego, zarządzanego w jednolity sposób (Khilafah, 2005, s. 11).

Mając na uwadze kontekst kulturowo-religijny zasadne wydaje się twierdzenie, że istnienie kalifatu było (i ciagle jest) nieuniknioną koniecznością. Koniecznością wynikającą z objawienia zawartego w Koranie i religijnym obowiązkiem (arab. wādżib) islamskiej wspólnoty. Uzasadnienie niezbędności jego istnienia nie ma zatem wiele wspólnego z przesłankami racjonalnymi. Muzułmanie potrzebują przywódcy, który stałby na straży porządku, zapobiegał wewnętrznym konfliktom i rodzącej się wskutek ich istnienia anarchii (Adam, 2001, s. 25-27). Konieczność istnienia kalifatu i kalifa, stojącego na 
straży prawa koranicznego, zauważał też Ibn Tajmijja. W komentarzu do hadisy zawierającej stanowisko Proroka na temat przywództwa jednego z jego Towarzyszy - 'Abd al-Rahmana, podkreślił, że każda, nawet najmniejsza grupa muzułmanów potrzebuje swego lidera. Oczywistym jest zatem fakt, iż większej grupie także musi przewodzić osoba ciesząca się autorytetem godnym tej funkcji (Adam, 2001, s. 27). Kolejną przesłanką konstytuującą ważność omawianej instytucji jest stanowisko Towarzyszy Proroka Mahometa wyrażone w zasadzie idżma al-sahaba, czyli powszechnej zgody, która doprowadziła do wyłonienia dwóch kalifów - Abu Bakra i Uthmana ibn Affana.

W przypadku społeczności szyickiej zarówno imamici, jak i ismailici uważają że to łaska Allaha (lutf) pozwala wskazać właściwego przywódcę (imama). Ten zaś, podążając ścieżką wyznaczoną przez Proroka Mahometa, powinien wskazywać szyitom właściwy kierunek i ostrzegać przed złem. Potrzeba posiadania przywódcy jest też u szyitów usprawiedliwiona argumentami racjonalnymi. Ich zdaniem idea imamatu przejawia się w uniwersalnym przywództwie jednostki w sprawach religijnych i świeckich (Adam, 2001, s. 30-31).

W opinii charydżytów natomiast istnienie kalifatu nie jest konieczne, aby muzułmanie mogli swobodnie realizować wszystkie religijne powinności. Kalifat może powstać w ostateczności, w sytuacji gdy byt muzułmanów, np. z uwagi na konflikt zbrojny, jest zagrożony.

Wszystkie powyższe grupy muzułmanów akceptują stanowisko, iż w konkretnym czasie islamskiej społeczności przewodzić może tylko jeden przywódca. Według sunnitów rządy dwóch kalifów w dwóch różnych państwach istnieć mogą tylko w ostateczności, gdy spełnione są określone warunki, np.: państwa te rozdzielone są morzem, co wyklucza możliwość udzielenia sobie nawzajem pomocy wojskowej, bądź nie istnieje możliwość kontaktu między nimi (Adam, 2001, s. 32). Wydaje się jednak, że w obecnych warunkach, całkowicie nieprzystających do czasów Proroka Mahometa, spełnienie tych wymogów jest mało prawdopodobne. Wyjątkowe stanowisko zajmują w powyższej sprawie mutazylici. Choć podzielają oni w istocie zdanie charydżytów, to sądzą (np. Abu Bakr al-Asamm), że w związku z ekspansją islamu dopuszczalne jest, aby każdy większy ośrodek (np. miejski) posiadał swego własnego kalifa (Adam, 2001, s. 35).

Rola kalifa w islamskim systemie władzy państwowej jest znacząca. Już zwolennicy szkoły hanbalickiej uznali za kluczowe (mając na uwadze rządy pierwszych czterech kalifów) stanie przez kalifa na straży wewnętrznego porządku i dbanie o to, aby spory i kłótnie nie doprowadziły do wewnętrznych podziałów (fitny) wewnątrz islamskiej wspólnoty. Mutazylici, a w szczególności Abd al-Dżabbar, twierdzili natomiast, że egzekwowanie prawa islamskiego możliwe jest tylko w ramach kalifatu, zaś brak kalifa oznacza brak możliwości egzekwowania islamskich kar (hudūd) za powszechnie występujące w społeczeństwie przestępstwa (np. kradzieże czy cudzołóstwo) (Adam, 2001, s. 23-24).

Sunnici i szyici zgadzają się co do tego, iż społeczność muzułmańska powinna posiadać tylko jednego przywódcę, który dbałby o poszanowanie islamskiego porządku i stał na straży prawa koranicznego. Potrzeba istnienia kalifatu wynikała więc z przyczyn zarówno funkcjonalnych, jak i religijnych.

Klasyczni muzułmańscy uczeni wielokrotnie wypowiadali się na temat koniecznych funkcji przypisanych kalifowi (lub imamowi). W przypadku sunnitów doktrynalne 
obowiązki kalifa dotyczą w szczególności: stania na straży prawa islamskiego i sprawiedliwe rozwiązywanie sporów pomiędzy muzułmanami, wymierzanie kar ( $h u d \bar{u} d)$, dbanie o pokój na obszarze zajmowanym przed wyznawców islamu i obrona tych ziem przed wrogami zewnętrznymi, prowadzenie dżihadu przeciwko tym, którzy opierają się zwierzchnictwu islamu, otrzymywanie środków finansowych z tytułu jałmużny (alms), podatków i dochodów wojennych (chums) i rozdzielanie ich zgodnie z prawem, i wreszcie powoływanie zaufanych przedstawicieli (Adam, 2001, s. 37-38).

W opinii Abu al-Hasana al-Mawardiego, jednego z bardziej znanych klasycznych uczonych analizujących funkcjonowanie kalifatu do zasadniczych funkcji kalifa, oprócz tych wspomnianych wyżej dodać można zaopatrzenie wojsk chroniących granice kalifatu, utrzymywanie i finansowanie administracji. Pomiędzy ósmym a dziesiątym wiekiem, a więc za panowania Abbasydów, kalif odpowiedzialny był przede wszystkim za stanie na straży prawa islamskiego (nie zaś za jego tworzenie). Kalifem powinna była być osoba o szczególnych przymiotach ducha i charakteru. Osoba, która byłaby w stanie utrzymać porządek w ramach kalifatu (choćby poprzez walkę z heretykami). Kalif powinien poza tym wskazać swojego następcę (co było praktykowane w ramach kalifatu umajjadzkiego) (Adam, 2001, s. 39-41).

Dyskusja na temat istoty kalifatu i funkcji kalifa toczona jest także wśród współczesnych islamskich uczonych. Dyskurs dotyczący ponownego utworzenia kalifatu i funkcji przypisywanych kalifowi trwa właściwie od momentu rozwiązania kalifatu otomańskiego. Jednym z ważniejszych współczesnych uczestników wspomnianej wyżej dyskusji był Muhammad Raszid Rida. Zdaniem Adama, Rida w pełni zgadzał się z klasycznym uzasadnieniem konieczności istnienia kalifatu. Był przekonany, że tylko kalifat jest $\mathrm{w}$ stanie zapewnić przestrzeganie prawa islamskiego. Uważał podobnie, jak Muhammad Abduh, iż celem istnienia kalifatu jest ochrona islamu przed wszelkimi innowacjami, promowanie jego prawa i wiary oraz pomaganie wspólnocie muzułmańskiej poprzez proces konsultacji (Adam, 2001, s. 41-42). Rida był także propagatorem zwołania kongresu w sprawie restytucji kalifatu do Kairu i Mekki w 1925 r. Ta inicjatywa zakończyła się jednakże fiaskiem z uwagi na czynniki obiektywne (brak sprzyjającego klimatu społeczno-politycznego do podjęcia takiej decyzji).

Kolejnym ważnym zwolennikiem kalifatu był Abu A’la al-Maududi. Był przekonany, że najważniejszym powodem jego istnienia jest obrona zarówno islamu, jak też i terytorium państwa islamskiego. Na gruncie społecznym celem tym miało być zbudowanie zbilansowanego systemu społecznej sprawiedliwości. Ten propagator politycznego islamu był też zwolennikiem silnego przywództwa, które uznał za istotny element swej koncepcji zmiany społecznej. Jakość tego przywództwa przekłada się jego zdaniem na siłę i znaczenie samego państwa. Tak ważne są zatem, jego zdaniem, przymioty osobiste lidera, w postaci kwalifikacji religijnych i moralnych (Adam, 2001, s. 42-43).

W przypadku społeczności szyickiej, jednym z najznamienitszych propagatorów idei imamatu był ajatollah Chomejni. Imamowi przypisane są szerokie kompetencje. W pierwszej kolejności są to kompetencje administracyjne. Odpowiada on poza tym za implementację prawa islamskiego i jego przestrzeganie. Adam podkreśla, że w interpretacji Chomejniego społeczność islamska nie może praktykować porządku islamskiego, jeśli imamat nie istnieje (Adam, 2001, s. 44-45). 


\section{Strategia budowy struktur wewnętrznych islamskiego protopaństwa}

Na przestrzeni ostatnich dwóch lat Państwo Islamskie znacząco poszerzyło swoje wpływy w świecie islamskim. Na Bliskim Wschodzie, w Afryce i Azji PołudniowoWschodniej pojawiły się nowe prowincje kalifatu. Znacząco wzrosła także liczba podmiotów, które złożyły przysięgę wierności kalifowi. Utrzymanie kontroli nad rosnącym obszarem wymagało podjęcia szeregu działań strategicznych i taktycznych oraz przeorganizowanie struktur wewnętrznych organizacji terrorystycznej w taki sposób, aby podołała ona nowym zadaniom. Analiza ewolucji Państwa Islamskiego wydaje się zatem znakomitym przykładem tworzenia struktur nowego protopaństwa.

W opinii Aarona Y. Zelina strategia budowy struktur państwowych Państwa Islamskiego złożona jest z dwóch etapów: kontroli przed całkowitym zajęciem terytorium i kontroli po zajęciu terytorium (Zelin, 2016, s. 1-24).

Tabela 2

Fazy i płaszczyzny budowy struktur Państwa Islamskiego w ujęciu A. Zelina

\begin{tabular}{|c|c|c|}
\hline & $\begin{array}{l}\text { FAZA I: PRE - LUB CZĘ́́CIOWA } \\
\text { KONTROLA NAD TERYTORIUM }\end{array}$ & $\begin{array}{c}\text { FAZA II: PELNA KONTROLA } \\
\text { NAD TERYTORIUM }\end{array}$ \\
\hline 1 & 2 & 3 \\
\hline WYWIAD & $\begin{array}{l}\text { Zbudowanie sieci tajnych komórek, infiltracja } \\
\text { innych grup, stworzenie grup frontowych }\end{array}$ & $\begin{array}{l}\text { Znalezienie wrogów i zaangażowanie się w ich } \\
\text { osaczanie: zapewnienie, aby wcześniejsi przy- } \\
\text { wódcy wyrazili skruchę i rozbroili się, stłu- } \\
\text { mienie wszelkich ruchów kontrrewolucyjnych, } \\
\text { pełna kontrola nad mediami (przekazem inter- } \\
\text { netowym, satelitarnym) }\end{array}$ \\
\hline WOJSKO & $\begin{array}{l}\text { Tworzenie obozów szkoleniowych, wykorzy- } \\
\text { stywanie asymetrycznej taktyki (najczęściej } \\
\text { partyzanckiej), wykorzystywanie snajperów, } \\
\text { improwizowanych ladunków wybuchowych, } \\
\text { samochodów pułapek, zamachów samobój- } \\
\text { czych }\end{array}$ & $\begin{array}{l}\text { Wykorzystywanie regularnych sił zbrojnych, } \\
\text { używanie szerokiego spektrum uzbrojenia } \\
\text { (m.in. czołgów i bojowych wozów opancerzo- } \\
\text { nych), organizowanie mobilizacji na szeroka } \\
\text { skalę, tworzenie stref buforowych, kierowanie } \\
\text { większej liczby bojowników na front. }\end{array}$ \\
\hline DA'WA & $\begin{array}{l}\text { Działania skierowane do miejscowej społeczno- } \\
\text { ści; organizowanie forum da'wa skierowanych } \\
\text { do ludzi młodych i dzieci; rozdawanie literatury } \\
\text { da'wa na ulicach, w sklepach i punktach kon- } \\
\text { troli; prezentowanie wywiadów z mieszkańca- } \\
\text { mi w oficjalnych mediach; spotykanie się, także } \\
\text { na posiłkach, z przywódcami lokalnych klanów } \\
\text { i innymi osobami }\end{array}$ & $\begin{array}{l}\text { Tworzenie instytucji medialnych, wykorzysty- } \\
\text { wanie bilbordów w celu wzmocnienia przeka- } \\
\text { zu propagandowego }\end{array}$ \\
\hline HISBA & $\begin{array}{l}\text { Niszczenie alkoholu, papierosów, fajek wod- } \\
\text { nych, narkotyków i wszelkich symboli zwią- } \\
\text { zanych z przesądami; niszczenie świątyń po- } \\
\text { gańskich, szyickich i sufickich, grobowców } \\
\text { i antycznych artefaktów; upewnianie się, że } \\
\text { mieszkańcy sukcesywnie uczestniczą w mo- } \\
\text { dłach i zamykają w tym czasie swe sklepy; } \\
\text { monitorowanie leków i żywności w celu upew- } \\
\text { nienia się, że nie straciły ważności, bądź się nie } \\
\text { zepsuły }\end{array}$ & $\begin{array}{l}\text { Ustanowienie porządku szariackiego (w tym } \\
\text { stosowanie przewidzianych tym porządkiem } \\
\text { kar); stosowanie kary chłosty; przywiązywa- } \\
\text { nie ludzi do słupów lub płotów z tabliczka- } \\
\text { mi wskazującymi na ich wykroczenia, celem } \\
\text { zniechęcenia innych osób do łamania prawa; } \\
\text { zamykanie ludzi w klatkach; obcinanie dłoni } \\
\text { i stóp; kamienowanie; ucinanie głowy; ukrzy- } \\
\text { żowanie. }\end{array}$ \\
\hline $\begin{array}{l}\text { ZARZA- } \\
\text { DZANIE }\end{array}$ & $\begin{array}{l}\text { Wprowadzanie podatków oraz arbitraż i łago- } \\
\text { dzenie sporów pomiędzy różnymi stronami; }\end{array}$ & $\begin{array}{l}\text { Zawieszanie czarnej flagi na słupach, budyn- } \\
\text { kach, lampach ulicznych; tworzenie tablic }\end{array}$ \\
\hline
\end{tabular}




\begin{tabular}{|l|l|l||}
\hline 1 & \multicolumn{1}{|c||}{2} & \multicolumn{1}{|c|}{3} \\
\hline $\begin{array}{l}\text { zapewnianie podstawowych usług społecznych } \\
\text { (m.in. dostępu do leków i żywności) }\end{array}$ & $\begin{array}{l}\text { informujących przyjezdnych o obecności struk- } \\
\text { tur państwowych (czasem zmiana nazwy miej- } \\
\text { scowości); inicjowanie programów robót pu- } \\
\text { blicznych (np. przekształcanie dróg żwirowych } \\
\text { w asfaltowe; przywracanie elektryczności; na- } \\
\text { prawianie, malowanie i czyszczenie dróg; dba- } \\
\text { nie o zieleń w przestrzeni publicznej; budowa } \\
\text { nowych meczetów, rynków i sklepów). }\end{array}$ \\
\hline
\end{tabular}

Legenda: $D a$ 'wa to: propagowanie islamu, prozelityzm. Hisba to: obowiązek kontroli przestrzegania prawa islamskiego, policja religijna, ochrona konsumentów.

Źródło: Zelin, McCants, 2016.

Kluczowe dla zrozumienia istoty powyższego procesu jest poddanie szczegółowej analizie każdej z pięciu płaszczyzn funkcjonowania struktur protopaństwa w odniesieniu do obu faz oddzielnie. W przypadku pierwszej fazy i pierwszej ze wskazanych płaszczyzn, a więc działalności wywiadu, ważne jest wskazanie, iż jej głównym celem jest rozbudowa struktury wywiadowczej poprzez tworzenie komórek wywiadowczych (najczęściej uśpionych, nieaktywnych). Ich aktywność operacyjna polegać może na infiltracji wrogów (np. innych grup partyzanckich) i powoływaniu własnych grup walczących z wrogiem. Dodatkowym zadaniem jest także identyfikowanie kluczowych postaci w grupach, które mogą stać się wrogami dżihadystów w perspektywie krótkoterminowej (Zelin, 2016, s. 1). Wywiad nie musi pozostawać bierny wobec wyzwań przed którymi stoi. W celu zwiększenia poparcia społecznego mogą mieć miejsce działania polegające na przekupywaniu lub przekonywaniu lokalnych klanów do poparcia Państwa Islamskiego. Równolegle wykorzystywane są różne metody walki asymetrycznej, których głównym zadaniem jest zdobycie jak największego wpływu na bieg wydarzeń na konkretnym terytorium. W ramach tej taktyki wykorzystywane być mogą działania partyzanckie, improwizowane ładunki wybuchowe, aktywność terrorystyczna czy snajperska. Przejawem takiej częściowej kontroli jest zajmowanie wiosek, małych miasteczek czy dzielnic w większych miastach. Przejęcie takiej częściowej kontroli umożliwia Państwu Islamskiemu rozpoczęcie działań mających związek z propagowaniem idei, za którymi się opowiadają (porządek szariacki). A. Zelin wskazuje na szereg interesujących technik propagowania islamu ( $\left.d a^{\prime} w a\right)$ wykorzystywanych przez dżihadystów, a adresowanych do dzieci i młodzieży, np. na: konkursy recytowania Koranu czy spożywania wybranych specjałów kuchni islamskiej (Zelin, 2016, s. 2). Działaniom $d a$ 'wa towarzyszy zazwyczaj wzmożona aktywność edytorska związana z publikowaniem propagandowej literatury kolportowanej na ulicach czy lokalnych rynkach. Kopie takich wydawnictw dostępne są także wirtualnie. Po zidentyfikowaniu kluczowych postaci w lokalnych społecznościach przedstawiciele Państwa Islamskiego próbują w pierwszej kolejności (w czasie wspólnych spotkań czy posiłków) przekonać je do złożenia przysięgi wierności kalifowi. Dżihadyści nie zaniedbująjednakże czynnych działań (hisba) mających związek z ustanowieniem już w ramach pierwszej fazy porządku szariackiego na częściowo kontrolowanym przez siebie obszarze. W tym celu niszczy się alkohol, papierosy, fajki wodne, narkotyki i wszelkie symbole mające związek z przesądami. Bardzo często niszczone są też zabytki (w tym świątynie i grobowce) mające związek z antycznymi praktykami politeistycznymi. Pilnowani są także mieszkańcy zamieszkujący zajęte przez Państwo Is- 
lamskie obszary. Chodzi o to, aby modlili się na czas, odbywali wspólne piątkowe modły i zamykali w tym czasie swoje sklepy. Dba się także o prawa konsumentów pilnując, aby leki czy żywność były bezpieczne. Ostatecznym potwierdzeniem przejmowania kontroli nad konkretnym obszarem jest ustanowienie podatków i utworzenie instytucji rozstrzygających, zgodnie z normami szariackimi, spory pomiędzy stronami (Zelin, 2016, s. 2-3). W ramach drugiej fazy budowy struktur państwowych ma miejsce intensyfikacja działań na wszystkich wskazanych wcześniej płaszczyznach. Warto jednak zauważyć, że znaczącą przeszkodą na drodze prowadzącej do tejże fazy jest fakt, iż większość prowincji Państwa Islamskiego znalazła się pod jego kontrolą w okresie ostatnich kilkunastu miesięcy. Tylko prowincje w Iraku i Syrii stanowić mogą zatem przykład efektywnego przejścia do tejże fazy. Aktywność służb wywiadowczych i kontrwywiadowczych w tym okresie związana jest przede wszystkim z identyfikacją i likwidacją osób prowadzących działalność szpiegowską lub dysydencką. Likwidowane lub rozbrajane są grupy, które prowadziły wcześniej autonomiczną aktywność paramilitarna. Nie mniej istotne jest kontrolowanie przepływu informacji, co wiąże się w szczególności z bardzo restrykcyjnymi regułami korzystania z internetu czy łączności bezprzewodowej (Zelin, 2016, s. 3).

Aktywność wojskowa prowadzona jest w tym okresie, zdaniem A. Zelina, przede wszystkim w klasyczny, regularny sposób (Zelin, 2016, s. 3), co nie oznacza, że nie są wykorzystywane inne metody walki (np. terroryzm). Walka regularna oznacza wykorzystywanie w praktyce ciężkiego uzbrojenia konwencjonalnego wszędzie tam, gdzie daje to stronie prowadzącej takie działania przewage taktyczną. Oznacza ona wreszcie konieczność mobilizacji sporej liczby żołnierzy, których wraz z uzbrojeniem trzeba przetransportować na linię frontu. Warto zauważyć, że brak wsparcia powietrznego takich sił lub brak broni przeciwlotniczej oznaczać może w praktyce taktyczną przewagę przeciwnika. Jedynym wyjściem dla Państwa Islamskiego jest w takiej sytuacji tworzenie stref buforowych, rozmieszczenie w kluczowych miejscach frontu własnych bojowników (murabitun) oraz wzmocnionych fortyfikacji (thughur) (Zelin, 2016, s. 3). Zajęcie i utrzymanie strategicznego terytorium było i jest jednak, jak dotąd, możliwe przede wszystkim dzięki słabości przeciwnika.

Kolejna płaszczyzna działań, związana z aktywnością $d a$ 'wa wiąże się przede wszystkim z rozbudową zdolności propagandowo-informacyjnych. Kluczową rolę w tym względzie pełnią centra medialne (nuktat al-alamaija). Mogą one mieć charakter stacjonarny lub mobilny, a więc znajdować się w zaadoptowanych do tego celu budynkach lub umieszczone być w przygotowanych do tego pojazdach. Udostępniane są tam na wielu nośnikach, ale także emitowane, programy propagandowe Państwa Islamskiego oraz dystrybuowana jest literatura dżihadystyczna. Często taka aktywność wsparta jest także bilbordami zawieszanymi w kluczowych punktach danej miejscowości, na których zauważyć można hasła religijne (związane np. z cytatem z hadisów) lub propagujące rządy kalifa (Zelin, 2016, s. 3-4). W ślad za powyższymi działaniami idą działania o bardziej zinstytucjonalizowanym charakterze, związane m.in. z wymierzaniem sprawiedliwości zgodnie z regułami prawa szariackiego (ukamienowanie, ukrzyżowanie, odcinanie rąk i nóg, obcinanie głów itp.), mające na celu zniechęcenie innych mieszkańców do łamania ustanowionego prawa. Potwierdzeniem sprawowania rządów Państwa Islamskiego jest wywieszanie w wielu różnych miejscach czarnych flag. Często też pojawiają się nowe znaki drogowe i tablice informacyjne potwierdzające istnienie kontroli Państwa Islamskiego nad danym teryto- 
rium. W ślad za działaniami symbolicznymi pojawiają się programy robót publicznych, związane m.in. z poprawą stanu dróg (z gruntowych czy żwirowych na asfaltowe), sprzątaniem czy porządkowaniem dróg i miejsc publicznych, naprawą linii telekomunikacyjnych i energetycznych, dbaniem o zieleń w miejscach publicznych czy wreszcie budową meczetów, lokalnych rynków czy sklepów. Niezmiernie ważne są też działania związane z dostarczeniem podstawowych usług publicznych (np. wody, energii elektrycznej) i uruchomieniem przedsiębiorstw dostarczających ważne dobra konsumpcyjne (np. żywność, lekarstwa czy materiały budowlane) (Zelin, 2016, s. 4-5). Wskazane powyżej działania Państwo Islamskie podjęło jedynie w wilajatach umiejscowionych na obszarze Iraku, Syrii czy Libii. W pozostałych aktywność państwotwórcza nie wyszła poza pierwszą fazę.

\section{Przyszlość Państwa Islamskiego}

Odpowiedź na pytanie o przyszłość Państwa Islamskiego nastręcza podobnych trudności do tych, które wiążą się ze wskazaniem istoty tego tworu. Początki istnienia analizowanego fenomenu wiążą się ściśle z aktywnością terrorystyczną i partyzancką. Mając na uwadze swoistą hybrydowość tego przedsięwzięcia brak jest przesłanek do stwierdzenia, iż Państwo Islamskie nie ma szans przetrwać jako organizacja terrorystyczna. Jeśli jednak bardziej zasadne jest używanie kategorii takich jak ,protopaństwo” czy „,kalifat”, to wówczas ostateczne konkluzje nie wydają się już tak oczywiste. Popularność idei nowego kalifatu wydaje się niewątpliwa. Przetrwanie tego państwa w średnio- czy długoterminowej perspektywie jest jednak dyskusyjne. W istocie żadne współczesne państwo nie jest $w$ stanie przetrwać bez utrzymywania przynajmniej neutralnych relacji z innymi uczestnikami stosunków międzynarodowych. Konfrontacyjna w wymiarze wojskowym i antyzachodnia w swym wymiarze politycznym strategia Państwa Islamskiego skazuje projekt odtworzenia kalifatu, przynajmniej w aktualnej formie, na porażkę.

Wypada zauważyć, że kompleksowość wyzwań, przed którymi dzisiaj stanęło Państwo Islamskie swego czasu zauważyli już przywódcy al-Kaidy, którzy powstrzymywali się od podobnych deklaracji w przeszłości. „Strategiczna cierpliwość” al-Kaidy obca jest bojownikom kalifatu. Zbyt wczesne przejście od fazy planowania do realizacji projektu tworzenia nowego państwa podważa w istocie sukces całego przedsięwzięcia. Sytuację komplikuje także dobór środków wykorzystywanych do realizacji tego celu. Apoteozowanie przemocy i pomijanie mniej spektakularnych działań zraża do projektu odtworzenia kalifatu znaczącą większość społeczności muzułmańskiej wyznającej umiarkowane poglądy. Państwo Islamskie zamiast perswazji stosuje opresję, a działania integrujące ummę zastępuje represjami. Przemoc spełnia swoją rolę tylko w krótkiej perspektywie czasowej. Projekty długofalowe, takie jak budowa kalifatu, wymagają szerokiego poparcia społecznego, na które dżihadyści z Państwa Islamskiego jeszcze nie zapracowali. Wnioski takie wywieść można ze studiów nad historią innych dżihadystycznych protopaństw powstałych w ostatnim ćwierćwieczu. $Z$ drugiej jednak strony wielu, spośród ponad 30000 bojowników Państwa Islamskiego, walczących w Iraku i Syrii, nie uznaje tej wizji za utopijną, doświadczając początków jej realizacji na własne oczy i oczekując szybkiego upadku swych wrogów. Ich oczekiwania i nadzieje są jednak raczej efektem skuteczności aktywności propagandowej ich współtowarzyszy, a nie recepcją aktualnej sytuacji nowego protopaństwa. 


\section{Bibliografia}

Adam F. (2001), The Concept of Khilafah According to Selected Sunni and Shi'i Qur'anic Commentaries, The University of Leeds, Department of Theology and Religious Studies, Leeds.

Ahmad R. (2016), The Islamic Khilafat - Its Rise, Fall, and Re-emergence, ,Al Islam”, http://www.alislam.org/egazette/updates/the-islamic-khilafat-its-rise-fall-and-re-emergence/, kwiecień 2016.

Brisard J.-C. (2005), Zarqawi. The New Face of Al-Qaeda, Other Press, New York.

Fishman B. (2008), Using the Mistakes of Al Qaeda's Franchises to Undermine Its Strategies, „Annals of the American Academy of Political and Social Science", vol. 618, Terrorism: What the Next President Will Face, July.

Gerges F. A. (2014), ISIS and the Third Wave of Jihadism, "Current History", vol. 113, no. 767, December.

Jordan confirms al Qaeda behind hotel blasts (2005), CNN International, http://www.cnn.com/2005/ WORLD/meast/11/12/jordan.blasts/index.html, kwiecień 2016.

Lahoud N., al-'Ubaydi M. (2014), The War of Jihadists Against Jihadists in Syria, "CTC Sentinel”, vol. 7, Issue 3, March.

Lia B. (2015), Understanding Jihadi Proto-States, "Perspectives on Terrorism", vol. 9, Issue 4.

Lister C. (2014), Profiling the Islamic State, Brookings Doha Center Analysis Paper, no. 13, November.

al-Tamimi A. J. (2014), Islamic State of Iraq and ash-Sham, "Current Trends in Islamist Ideology", Hudson Institute, vol. 16, March.

al-'Ubaydi M., Lahoud N., Milton D., Price B. (2014), The Group That Calls Itself a State: Understanding the Evolution and Challenges of the Islamic State, The Combating Terrorism Center at West Point, New York.

Web site links al-Zarqawi to Iraq oil attacks (2004), CNN International, 26.04, http://edition.cnn. com/2004/WORLD/meast/04/26/iraq.zarqawi/index.html, kwiecień 2016.

Zelin A. Y. (2014), The War between ISIS and al-Qaeda for Supremacy of the Global Jihadist Movement, The Washington Institute for Near East Policy, „Research Notes”, no. 20, June 2014.

Zelin A. Y. (2016), The Islamic State's Territorial Methodology, The Washington Institute for Near East Policy, Research Notes, no. 29, January.

Zelin A. Y., McCants W. (2016), Experts weigh in (part 3): Is ISIS good at governing?, Brookings Institute, February 9, http://www.brookings.edu/blogs/markaz/posts/2016/02/09-experts-weighin-isis-governance-zelin-mccants, kwiecień 2016.

\section{Islamic State - the new phenomenon of jihadi quasi-state}

\section{Summary}

This article focuses on four major issues: the nature and main characteristics of the so-called jihadi quasi-state; a review of past and current jihadist emirates; the history of the Islamic State (the name can be understood in two ways: as a jihadi organization and quasi-state which control territory); and the immediate future of a new jihadi quasi-state.

Key words: Islamic State, jihadism, Iraq, Syria, terrorism, caliphate, guerrilla warfare 
